\title{
Food packaging and its regulations in Mexico
}

\section{Empaques para alimentos y su normatividad en México}

\author{
HERNÁNDEZ-TINOCO, Araceli†, CARBAJAL-MARISCAL, Oscar and MORÁN-SALAS, María \\ Cristina \\ Centro Universitario de Ciencias Biológicas y Agropecuarias, CUCBA de la Universidad de Guadalajara. Camino Ramón \\ Padilla Sánchez 2100 Nextipac, 45200 Zapopan, Jal. México.
}

ID $1^{\text {st }}$ Author: Araceli, Hernández-Tinoco / ORC ID: 0000-0002-8420-0530- 95748

ID $1^{\text {st }}$ Coauthor: Oscar, Carbajal-Mariscal / ORC ID: 0000-0001-5373-3062-242918

ID $2^{\text {nd }}$ Coauthor: María Cristina, Morán-Salas / ORC ID: 0000-0002-8458-2241- 948550

DOI: $10.35429 / J L E .2019 .4 .3 .9 .17$

Received March 12, 2019; Accepted June 25, 2019

\begin{abstract}
Objective: To identify the context in terms of legislation for food packaging in Mexico. Methodology: A qualitative documentary investigation to obtain from Mexican national official and institutional primary sources the existing published information regarding food packaging. The information was recovered, analyzed, classified and organized by food groups, as is done in other international references. Contribution: This paper presents a description of the parameters that regulates food packaging based on the existing regulations for food in Mexico and its sources. From the analysis of the information obtained, this paper contributes to the dissemination of the existing Mexican regulations for the packaging of food products and the degree of inclusion of the needs of Mexican consumers in this matter regarding the form as presented in the United States in its CODEX and in the European Union. A brief discussion of the food groups, their social impact and the comparison in proportion of existing legislation for their packaging and the number of products marketed are presented.
\end{abstract}

\begin{abstract}
Resumen
Objetivo: Identificar el contexto en materia de legislación para envases de alimentos en México. Metodología: Se realizó una investigación documental cualitativa, para obtener de fuentes primarias oficiales e institucionales nacionales mexicanas, la información existente publicada referente a envases para alimentos. Se recuperó, analizó, clasificó y organizó la información por grupos de alimentos, tal como se realiza en otras legislaciones internacionales. Contribución: En este trabajo se presenta una descripción de los parámetros que regulan los envases para alimentos a partir de las normas existentes vigentes para alimentos en México y sus fuentes de obtención. A partir del análisis de la información obtenida, se contribuye a la difusión de la normatividad mexicana en las regulaciones para los envases de los productos alimenticios y se manifiesta el grado de inclusión de las necesidades de los consumidores mexicanos en esta materia respecto a la forma como se presenta en Estados Unidos en su CODEX y en la Unión Europea. Se presenta una breve discusión de los grupos de alimentos, su impacto social y la comparación en proporción de legislación existente para sus envases y el número de productos comercializados.
\end{abstract}

Envases, Alimentos procesados, Regulación 


\section{Introduction}

Food and diet are a basic need of humanity that goes beyond mere nutrition and health to become even a sociological component.

Throughout the ages, food has been a universal means of communication, sociability, identification and behavior in a society, thus establishing a biological, nutritional, social, psychological, economic, symbolic and religious interaction (Contreras, 2002). In the description of the history of food, the subject of packaging, which in Mexico is used as a synonym to containers, is necessarily included and the factors that imply its development. Food packaging has an integral role that goes beyond what was initially established only to protect and transport. Now the packages conserve, add nutrients and preservatives, inform about their handling conditions, feed, prevent, provide status and benefits, among other uses.

Packaging has evolved from containers made from animal casings and ceramics in ancient times, to 19th century glass cans and bottles, to aseptic plastic and aluminum containers, to active, intelligent, radio frequency capable, flexible, zippered containers, to 20th century moldable plastic containers, coextrusion of films and two-piece aluminum cans. Technology in the 21 st century, on the other hand, offers containers for microwave ovens, dispenser closures, packaging with modified atmospheres, with prolonged release of active ingredients into the food, cans with multiple layers of plastic, trays with high resistance to temperature and flexible or sterilizable packaging that can be cooked in the container, among others.

In the use of food packaging we can find various materials like traditional, glass, wood and paper, to the last generation, such as plastics, metal, the so-called tetrapack and biodegradable materials, as the most important. Most of the authors agree that the priority of packaging is to protect the food from the place of origin to the moment of consumption, by delaying its deterioration due to contamination or exposure to the environment by protecting it from light, heat, humidity, microorganisms, oxygen, mechanical damage, insects, dust and dirt, thus extending its useful life (Careaga, 1993).
On the other hand, it is important to consider the impact on health, related to the fact that it is the same containers used to protect food that are directly responsible for harmful effects on health, when these plastic containers, due to their polymeric characteristics, they require organic solvents to maintain their flexibility and mechanical characteristics that give them their physical advantages in handling and as food containers; these solvents are toxic to humans when ingested through the food they contain. An example of the above is bisphenol A (BPA), a solvent used mainly for the manufacture and hardening of plastics, commonly used in baby bottles, tableware, water and milk bottles. The use of these containers keeps the consumer exposed to this substance. In studies conducted by the World Health Organization (WHO), it was presented that at doses higher than $2 \mu \mathrm{g} / \mathrm{kg}$ body weight/day it caused harmful effects on the prostate, while for a poisoning the maximum amount was considered to be $475 \mathrm{mg} / \mathrm{kg}$ body weight/day) (UN, 2010). For the selection of food packaging in Mexico, there is the national commercial and industrial regulations given by the Mexican Official Standards (NOM), which are mandatory. They are issued by government agencies. There are also voluntary standards (NMX.CC) that can be applied at local, regional or national level. They are equivalent to ISO 9000 standards. Certificates and analyses are carried out in laboratories recognized by the National Accreditation System and the National Construction Laboratory (Packaging and standards, 2019).This legislation seeks to cover three basic aspects for the packaging of consumer products:

- "Consumer Protection" deals with materials in contact with food; with hygiene and sanitary practices during the food manufacturing process; with laws on the handling and transport of dangerous goods; and with technical specifications related to the design of containers and packaging.

- Environmental care: deals with waste management and handling systems in relation to packaging, laws controlling materials and packaging processing practices.

- Business practices: deals with the market and labelling of packaging. (Publicidad $y$ Nutrición, 2019). 
The laws in Latin America are based mainly on what is indicated by Mercosur and the World Trade Organization (WTO), with their respective variations or modifications between locations. Mercosur "has agreed that the containers and packaging of food products, as well as the implements and tools that participate in their production process, must be sanitary; this applies to basic materials such as plastics, elastomers, metals, glass and ceramics" (Publicidad y Nutrición, 2019).

Many new food products appear on market shelves and in shops every day, but neither the packaging nor its legislation evolves at the same pace, nor do they offer the safety they claim to do. The objective of this paper is to identify the context of food packaging legislation in Mexico. The hypothesis proposed is that in Mexico there are not enough regulatory standards covering the whole range and variety of processed food products in the national market.

\section{Methodology}

A qualitative documentary research was carried out in order to obtain, from primary official and institutional Mexican national sources, the existing information published regarding food packaging. The information was recovered, analyzed, classified and organized by food groups, according to the data registered in the General Directorate of Standards, in order to compare it with other international legislations. Other sources of packaging regulations in Mexico were consulted, among them:

- Ministry of Economy (SE).

- National Chambers of Commerce.

- Ministry of Health.

- Mexican Packaging Association (AMEE).

\section{Results and discussion}

\section{Definition of packaging}

For the purpose of information analysis, packaging must be defined according to Mexican standards and these are:
Container: It is the adequate container that is in contact with the product to protect and preserve it and that facilitates its handling, storage and distribution.

Packaging: Everything that groups, contains and properly protects packaged products, facilitating handling in transport and storage operations and identifying their contents. What is of interest for this work is the container, since it is the one that is directly in contact with the food.

Since the definition does not include that it does not contain compounds that are transferred to the food, "adequate container" leaves many options for the decision of its use.

FAO states that the role of packaging is to protect processed foods from light, moisture and other environmental contaminants (FAO, 2019).

Mexican regulations on packaging. The search yielded a total of 24 NOMs, 38 NMXs and 2 Draft Standards that regulate packaging and containers in different industries, from food to hazardous waste management. All these standards are in force. They are not classified in groups and that makes their search in the system complicated.

Mexican Official Standards (Secretaría de Economía, 2019)

1- NMX-EE-010-NORMEX-2004: ENVASE Y EMBALAJE-ENVASES METALICOS PARA CONTENER ALIMENTOSTERMINOLOGIA (CANCELA A LA NMX-EE-010-1988).

2- NMX-EE-011-S-1980: ENVASE Y EMBALAJE. - METALES. - ENVASES DE HOJALATA - CILINDROS SANITARIOS, PARA CONTENER ALIMENTOS. ESPECIFICACIONES

3- NMX-EE-022-1983: ENVASE Y EMBALAJE - RESISTENCIA A LA TENSION EN PAPEL Y CARTON PLEGADIZO - ENERGIA ABSORBIDA (TEA) - METODO DE PRUEBA 
4- NMX-EE-038-1981: ENVASE Y EMBALAJE-CARTON Y PAPELMETODO DE PRUEBA PARA LOS ADHESIVOS EMPLEADOS EN CARTONES Y PAPELES

5- NMX-EE-039-1979: ENVASE Y EMBALAJE- ENVASES Y EMBALAJES DE CARTON- DETERMINACION DE LA RESISTENCIA A LA COMPRESION

6- NMX-EE-048-SCFI-2004: INDUSTRIA AZUCARERA-SACOS DE POLIPROPILENO, SACOS CON LINER DE POLIETILENO Y SACOS LAMINADOS PARA ENVASAR AZUCAR-ESPECIFICACIONES Y METODOS DE PRUEBA (CANCELA A LA 7- NMX-EE-059-NORMEX-2000: ENVASE Y EMBALAJE-SIMBOLOS PARA MANEJO, TRANSPORTE Y ALMACENAMIENTO (CANCELA A LA NMX-EE-059-1979).

8- NMX-EE-064-NORMEX-2005: ENVASE Y EMBALAJE-ENVASES CILINDRICOS SANITARIOS DE HOJALATADIMENSIONES, ESPECIFICACIONES Y METODOS DE PRUEBA (CANCELA LA NMX-EE-064-S-1979).

9- NMX-EE-073-NORMEX-2004: ENVASE Y EMBALAJE-METALES-ENVASES DE HOJALATA CILINDRICOS SANITARIOS PARA CONTENER ALIMENTOSDETERMINACION DE LA HERMETICIDAD-METODO DE PRUEBA (CANCELA A LA 10

10- NMX-EE-074-1980: ENVASE Y EMBALAJE- PAPEL Y CARTONTERMINOLOGIA

11- NMX-EE-075-1980: ENVASE Y EMBALAJE- PAPEL Y CARTONDETERMINACION DE LA RESISTENCIA AL REVENTAMIENTO

12- NMX-EE-095-1980: ENVASE Y EMBALAJE- MADERADETERMINACION DE LOS DEFECTOS EN MADERAS ASERRADAS Y CEPILLADAS
13- NMX-EE-097-NORMEX-2004: ENVASE Y EMBALAJE-METALES-ENVASES DE HOJALATA CILINDRICOS SANITARIOS PARA CONTENER ALIMENTOSMEDICION DE DEFECTOS-METODO DE PRUEBA (CANCELA A LA NMX-EE-097S-1980).

14- NMX-EE-108-1981: ENVASE Y EMBALAJE - PAPEL Y CARTONDETERMINACION DE LA RESISTENCIA AL RASGADO

15- NMX-EE-114-1985: ENVASE - VIDRIO TERMINOLOGIA

16- NMX-EE-119-S-1982: ENVASEMETALES- EVALUACION DE LA EXPOSICION DEL METAL EN ENVASES METALICOS QUE CONTENGAN BEBIDAS CARBONATADAS Y CERVEZA

17- NMX-EE-123-1981: ENVASE Y EMBALAJE- CARTON COMPACTO Y CORRUGADO- DETERMINACION DEL COEFICIENTE DE FRICCION ESTATICA- METODO DEL PLANO INCLINADO

18- NMX-EE-124-1988: ENVASE VIDRIO. CLASIFICACION DE LAS CORONAS.

19- NMX-EE-126-NORMEX-2004: ENVASE Y EMBALAJE-METALES-ENVASES DE HOJALATA CILINDRICOS SANITARIOS PARA CONTENER ALIMENTOSEVALUACION DEL CIERRE-METODO DE PRUEBA (CANCELA A LA NMX-EE126-S-1981).

20- NMX-EE-127-1981: ENVASE Y EMBALAJE - MADERA - CLAVADO DE CAJAS - ESPECIFICACIONES

21- NMX-EE-130-1981: 6ENVASE 1- VIDRIO - CORONAS DE ROSCA ESPECIFICACIONES

\begin{tabular}{lll}
$22-$ & NMX-EE-131-1986: & \multicolumn{2}{c}{ ENVASE } \\
METALES - TAPAS PARA USO \\
COMERCIAL - MATERIALES & - \\
ESPECIFICACIONES &
\end{tabular}

22- NMX-EE-131-1986: ENVASE METALES - TAPAS PARA USO ESPECIFICACIONES 
23- NMX-EE-133-NORMEX-2004: ENVASE Y EMBALAJE-METALES-ENVASES DE HOJALATA SANITARIOS PARA CONTENER ALIMENTOSDETERMINACION DEL ESTAÑO LIBRE Y ALEACION-METODO DE PRUEBA (CANCELA A LA 26-

\section{4- NMX-EE-137-1982: ENVASE Y EMBALAJE- MADERA- DETERMINACION DE LA FLEXION ESTATICA.}

25- NMX-EE-143-1982: $\quad$ ENVASEPELICULAS PLASTICASDETERMINACION DE LA RESISTENCIA DEL SELLADO A LA TENSION

26- NMX-EE-147-NORMEX-2004: ENVASE Y EMBALAJE-METALES-ENVASES DE HOJALATA SANITARIOS PARA CONTENER ALIMENTOSDETERMINACION DE LA CAPA BARNIZ-METODO DE PRUEBA (CANCELA A LA NMX-EE-147-1982).

27- NMX-EE-148-1982: ENVASE Y EMBALAJE - TERMINOLOGIA BASICA

28- NMX-EE-154-NORMEX-2004: ENVASE Y EMBALAJE-METALES-TAPAS INVIOLABLES-ESPECIFICACIONES (CANCELA A LA NMX-EE-154-1986).

29- NMX-EE-155-1984: ENVASE Y EMBALAJE - ENVASE - METALES TAPAS PARA USO COMERCIAL TERMINOLOGIA Y DEFINICIONES

30- NMX-EE-161-1983: ENVASE Y EMBALAJE - EMBALAJE - CARRETES DE MADERA PARA CONDUCTORES ELECTRICOS Y TELEFONICOS ESPECIFICACIONE

31- NMX-EE-169-1984: ENVASE Y EMBALAJE- CARTON- RESISTENCIA A LA FLEXION Y A LA COMPRESIONMETODO DE PRUEBA

$\begin{array}{lrr}\text { 32- NMX-EE-172-1984: } & \text { ENVASE- } \\ \text { METALES- ENVASES } & \text { METALICOS- } \\ \text { DETERMINACION } & \text { DE } & \text { SUS } \\ \text { DIMENSIONES NOMINALES. } & \end{array}$

33- NMX-EE-173-1986: ENVASE - SACOS DE PAPEL - TERMINOLOGIA

34- NMX-EE-175-1984: ENVASE Y EMBALAJE - CARTON CORRUGADO RIGIDEZ - METODO DE PRUEBA

35- NMX-EE-197-NORMEX-2004: ENVASE Y EMBALAJE-METALES-TAPAS ROSCADAS PARA ENVASES DE VIDRIO Y PLASTICO-SERIES 400, 410, 415 Y 425 (CANCELA A LA NMX-EE-197-1986).

36- NMX-EE-202-1987: ENVASES Y EMBALAJE - MADERA- CAJAS PARA EXPORTACION DE MERCANCIAS HASTA DE $1400 \quad$ KG ESPECIFICACIONES.

37- NMX-EE-208-1984: ENVASE Y EMBALAJE - CARTON - RESISTENCIA A LA PERFORACION - METODO DE PRUEBA

38- NMX-EE-221-1990: INDUSTRIA DEL PLASTICO - ENVASE Y EMBALAJE ESPESOR DEL SACO INDUSTRIAL METODO DE PRUEBA

Of the total number of standards mentioned above, only 38 standards are for food or food-related.

\section{Standards by food groups}

For packaging, in the Mexican regulations, there is no classification by the products for which the containers are intended, so it is complicated to look for containers only for food and we had to look for all material relating to packaging and then discriminate by content the ones that were related to food. Even much of the information for packaging is implicit in the standard, so the title is not directly informative of its content.

Of the 38 standards found for foods, 5 standards refer to the group of foods known as dairy products, followed by the group of meat products with 3 standards, and at the end are fruits and vegetables with only one Mexican standard that makes special mention of them. The number of standards does not correspond to the variety of products on the market. Thus, producers are limited to using packaging that is either not prohibited or not mentioned as contraindicated in the standards.

HERNÁNDEZ-TINOCO, Araceli, CARBAJALMARISCAL, Oscar and MORÁN-SALAS, María Cristina. Food packaging and its regulations in Mexico. Journal-Law and Economy. 2019 
If they are not prohibited, they are allowed. Packaging suppliers recommend the best containers to transport the food but not the best safe vehicles in all cases, especially when it comes to plastic packaging containing chemicals that are transferred to the food and give it that characteristic plastic taste that has already become normalized among the population and that, since it does not offer rejection by the consumer, is still used. The food group with the greatest regulation is dairy products due to the great variety of products derived from them: powdered, whole, pasteurized, ultra-pasteurized, micro-filtered, evaporated, rehydrated, lactose free, concentrated, flavored, to mention a few. Because of this, there are several containers or packages that contain the product, mostly plastic bags, plastic cans, aluminum cans and, in some rare cases, glass.

\section{Parameters regulated by packaging standards}

The points that the standards emphasize most are that they should be sanitary type containers, made of safe materials and resistant to different stages of the process, so that they do not react with the product or alter the physical, chemical and sensory characteristics. On the other hand, the material should offer adequate protection to prevent external deterioration, which would facilitate handling, storage and distribution. Packaging materials include metallic materials, glass, paper, cardboard, plastics, wood and even textiles. Each has different regulations and specifications, which are shown in the following table:

\begin{tabular}{|l|l|}
\hline Material & \multicolumn{1}{|c|}{ Regulation } \\
\hline Metallic & Risk of poisoning from eating lead- \\
contaminated food. & Material (must not contain lead) \\
& Type of closure \\
& Soldering (no lead soldering) \\
& Sewing \\
& Coating \\
& Harmlessness \\
& No bad smells \\
& The dimensions of cylindrical tinplate food \\
& containers are set \\
\hline Paper and & It specifies the measurements and \\
cardboard & characteristics. \\
& Materials (mainly corrugated cardboard) \\
& Adhesives (not to be dissolved in water) \\
& Construction \\
& Ventilation \\
& Close \\
& Compressive strength \\
& Tear resistance \\
& Resistance to bursting \\
& Bending \\
& Puncture resistance. \\
\hline
\end{tabular}

\begin{tabular}{|c|c|}
\hline Plastic & $\begin{array}{l}\text { Specifications to be met by the bottle. } \\
\text { Volume } \\
-1000 \mathrm{ml} \\
-500 \mathrm{ml} \\
\text { Hermeticity } \\
\text { Impact resistance } \\
\text { Compression } \\
\text { Material } \\
\text { - TYPE 1: PVC bottle of one-liter capacity. } \\
\text { - TYPE 2: Half-liter capacity PVC bottle. }\end{array}$ \\
\hline Glass & $\begin{array}{l}\text { Sets the specifications for lime glass } \\
\text { containers } \\
\text { intended to contain food in general. } \\
\text { Material } \\
\text { - Classification } \\
\text { Height } \\
\text { Diameter } \\
\text { Capacity } \\
\text { Verticality } \\
\text { Crown } \\
\text { Thermal shock } \\
\text { Residual Efforts } \\
\text { Chemical Resistance }\end{array}$ \\
\hline Wood & $\begin{array}{l}\text { It regulates the quality of the wood and } \\
\text { phytosanitary qualities. } \\
\text { Defects } \\
\text { - Chopped wood } \\
\text { - Pests } \\
\text { - Chips } \\
\text { - Stains } \\
\text { - Nailed } \\
\text {-Resistance }\end{array}$ \\
\hline Ceramics & Limits are set for lead and cadmium. \\
\hline Textile & $\begin{array}{l}\text { Quality specifications to be met by bags or } \\
\text { sacks made of sisal threads used for } \\
\text { packaging, storage and transport. } \\
\text { Thread } \\
\text { - Type I } \\
\text { - Warp threads } / 5 \mathrm{~cm} 10 \pm 0.5 \text { threads } \\
\text { - Threads in the weft } / 5 \mathrm{~cm} 11 \pm 0.5 \text { threads } \\
\text { - The measurements of the sack should be as } \\
\text { follows: width }(80 \mathrm{~cm} \pm 2 \mathrm{~cm}) \text { and }(120 \mathrm{~cm} \pm \\
2 \mathrm{~cm}) \text { length. } \\
\text { - Type II } \\
\text { - Warp threads } / 5 \mathrm{~cm} 9 \pm 0.5 \text { threads } \\
\text { - Threads in the weft } / 5 \mathrm{~cm} 7 \pm 0.5 \text { threads } \\
\text { - The measurements of the sack should be as } \\
\text { follows: width }(85 \mathrm{~cm} \pm 2 \mathrm{~cm}) \text { and }(125 \mathrm{~cm} \pm \\
2 \mathrm{~cm}) \text { length. } \\
\text { Finish } \\
\text { Resistance }\end{array}$ \\
\hline
\end{tabular}

Table 1 Descriptors of current Mexican regulations for different food packages

Source: Prepared by the authors

National regulations do not describe or specify food group materials. In many cases there are no regulations for many foods, so international legislation is consulted like the Food \& Drugs Administration (FDA) or the European Union, or similar products are sought to provide selected packaging with support. Otherwise, the suppliers' offers are also used based on their experience and customs. Table 2 below presents the description and use of the different packaging materials commonly used in food.

HERNÁNDEZ-TINOCO, Araceli, CARBAJALMARISCAL, Oscar and MORÁN-SALAS, María Cristina. Food packaging and its regulations in Mexico. Journal-Law and Economy. 2019 
June, 2019 Vol.3 No.4 9-17

\begin{tabular}{|c|c|c|}
\hline \multirow{2}{*}{\multicolumn{3}{|c|}{$\begin{array}{l}\text { Description } \\
\text { Metallic }\end{array}$}} \\
\hline & & \\
\hline $\begin{array}{l}\text { like aluminium } \\
\text { and tinplate (with } \\
\text { varnish coating), } \\
\text { they offer } \\
\text { airtightness, } \\
\text { inviolability, } \\
\text { resistance to } \\
\text { thermal } \\
\text { processes, } \\
\text { resistance to long } \\
\text { transports. }\end{array}$ & $\begin{array}{l}\text { Tinplate containers } \\
\text { are not normally } \\
\text { found as packaging } \\
\text { in the food industry. } \\
\text { Generally, it applies } \\
\text { for canned fish and } \\
\text { meat, but also for } \\
\text { vegetable pickles, } \\
\text { beer, juices. }\end{array}$ & $\begin{array}{l}\text { (Lara, 2005), } \\
\text { (López, } \\
\text { 2008), } \\
\text { (Pérez, } \\
\text { 2012) }\end{array}$ \\
\hline \multicolumn{3}{|l|}{ Plastic } \\
\hline $\begin{array}{l}\text { They are } \\
\text { polymers } \\
\text { composed of } \\
\text { organic } \\
\text { macromolecules } \\
\text { used in the form } \\
\text { of resins of which } \\
6 \text { types are } \\
\text { commonly used } \\
\text { (PET, HDPE, } \\
\text { PVC, LDPE, PP } \\
\text { and PS of 50 that } \\
\text { exist on the } \\
\text { market) } \\
\text { representing 95\% } \\
\text { of the plastics } \\
\text { used in food. }\end{array}$ & $\begin{array}{l}\text { Snacks, cereals, } \\
\text { fruits, } \\
\text { vegetables, etc. }\end{array}$ & $\begin{array}{l}\text { (Lara, 2005), } \\
\text { (López, } \\
\text { 2008) }\end{array}$ \\
\hline \multicolumn{3}{|l|}{ Cardboard } \\
\hline $\begin{array}{l}\text { These are } \\
\text { packages } \\
\text { essentially made } \\
\text { of cellulose } \\
\text { fibers, forming } \\
\text { thin or thick } \\
\text { laminates in } \\
\text { paper, pressed } \\
\text { cardboard, } \\
\text { folding carton } \\
\text { and corrugated } \\
\text { board } \\
\text { presentations. }\end{array}$ & $\begin{array}{l}\text { It is often used as } \\
\text { packaging material } \\
\text { or as a temporary } \\
\text { wrap or provided } \\
\text { with a plastic coating } \\
\text { for meat. }\end{array}$ & $\begin{array}{l}\text { (Lara, 2005), } \\
\text { (López, } \\
\text { 2008), } \\
\text { (Grisales, } \\
\text { 2004) }\end{array}$ \\
\hline \multicolumn{3}{|l|}{ Wood } \\
\hline $\begin{array}{l}\text { It is a highly } \\
\text { resistant, durable } \\
\text { and degradable } \\
\text { packaging, it } \\
\text { fulfills a thermal } \\
\text { function, allows } \\
\text { easy storage. } \\
\text { However, it } \\
\text { offers difficulty } \\
\text { in cleaning and } \\
\text { disinfection, does } \\
\text { not offer } \\
\text { standardization } \\
\text { and generates } \\
\text { problems in the } \\
\text { abrasion of the } \\
\text { product. }\end{array}$ & $\begin{array}{l}\text { It is used as } \\
\text { packaging and } \\
\text { transport material for } \\
\text { fresh fruits and } \\
\text { vegetables. }\end{array}$ & $\begin{array}{l}\text { (Lara, 2005), } \\
\text { (López, } \\
\text { 2008), } \\
\text { (Villada, } \\
\text { 2007) } \\
\text { (Pérez, } \\
\text { 2012) }\end{array}$ \\
\hline
\end{tabular}

\begin{tabular}{|c|c|c|}
\hline \multicolumn{3}{|l|}{ Glass } \\
\hline $\begin{array}{l}\text { It is a vitreous } \\
\text { material formed } \\
\text { from silica, } \\
\text { calcium and } \\
\text { sodium. The glass } \\
\text { containers are } \\
\text { prepared under } \\
\text { molding and } \\
\text { blowing } \\
\text { specifications } \\
\text { offering } \\
\text { advantages such } \\
\text { as being a } \\
\text { chemically inert } \\
\text { material, resistant } \\
\text { to } \\
\text { temperatures and } \\
\text { chemical agents, } \\
\text { can be pigmented } \\
\text { to protect food. }\end{array}$ & $\begin{array}{l}\text { It is commonly used } \\
\text { for preserves and } \\
\text { fruits, wines and } \\
\text { liquors, soft drinks } \\
\text { and pharmaceuticals. }\end{array}$ & $\begin{array}{l}\text { (Lara, 2005), } \\
\text { (López, } \\
2008) \\
\text { (Pérez, } \\
\text { 2012) }\end{array}$ \\
\hline \multicolumn{3}{|l|}{ Laminates } \\
\hline $\begin{array}{l}\text { These are } \\
\text { containers made } \\
\text { from other } \\
\text { flexible } \\
\text { materials: } \\
\text { plastics, paper, } \\
\text { thin metal sheets, } \\
\text { by extrusion } \\
\text { method. This type } \\
\text { of packaging } \\
\text { combines the } \\
\text { characteristics of } \\
\text { various materials } \\
\text { to increase the } \\
\text { performance of a } \\
\text { product, for } \\
\text { example: the } \\
\text { strength of the } \\
\text { paper, the } \\
\text { thermal-hermetic } \\
\text { seal of the plastic } \\
\text { and the } \\
\text { impermeability of } \\
\text { the aluminum. }\end{array}$ & $\begin{array}{l}\text { Snacks, chocolates, } \\
\text { semi-rigid for milk } \\
\text { and juice containers, } \\
\text { rigid for ready-to-eat } \\
\text { or commonly pre- } \\
\text { cooked dishes. }\end{array}$ & $\begin{array}{l}\text { (Lara, 2005), } \\
\text { (López, } \\
\text { 2008), } \\
\text { (Careaga, } \\
\text { 1993), } \\
\text { (Envapack, } \\
\text { 2011) }\end{array}$ \\
\hline \multicolumn{3}{|l|}{ Aluminum } \\
\hline $\begin{array}{l}\text { Aluminum is a } \\
\text { recyclable } \\
\text { material that is } \\
\text { also used to } \\
\text { produce cans. }\end{array}$ & $\begin{array}{l}\text { Some thin sheet } \\
\text { aluminum containers } \\
\text { are currently used in } \\
\text { the industry, such as } \\
\text { trays, saucers, trays } \\
\text { that are used to } \\
\text { distribute and } \\
\text { preserve frozen, } \\
\text { baked or ready-to-eat } \\
\text { foods. } \\
\text { It is also used in } \\
\text { carbonated drinks, } \\
\text { juices and beverages. }\end{array}$ & $\begin{array}{l}\text { (Pérez, } \\
\text { 2012) }\end{array}$ \\
\hline
\end{tabular}

Table 2 Materials used in the manufacture of food packaging

Source: prepared by the authors
HERNÁNDEZ-TINOCO, Araceli, CARBAJALMARISCAL, Oscar and MORÁN-SALAS, María Cristina. Food packaging and its regulations in Mexico. Journal-Law and Economy. 2019 
They all refer to the physical quality of the package, physical and mechanical resistance, closure, presentation, dimensions, but none to the reactions with the foods contained so they do not present any list of foods contraindicated by their chemical characteristics or composition that have a problem with the package, because of the possible reactions with it in some way. Nor do they refer to preferential temperature conditions for use in food.

\section{Plastics as a food packaging material.}

In relation to the plastics so widely used in the world, these come from oil, a non-renewable resource. In the beginning, polyvinyl chlorate or PVC was one of the most widely used and permitted materials for food packaging. Today the risks of its use are known, since even in its handling and manufacture it generates a high risk for workers in contact with it, like liver cancer (Public Health Summary, 2019).

Another material widely used in food is PET Polyethylene terephthalate, which is made by combining ethylene glycol and terephthalic acid at high temperature and low pressure to form a polymer chain. PET is highly resistant to chemical or biological reactions with other substances (Perez, 2012, PET Resin Association, 2015). According to a study by Forrest (2019), PET can be recycled and reused in foods. The FDA has generated and established the guidelines and conditions for the reprocessing of plastics, to ensure that they are safe to use in food (FDA, 2018).

Mexican legislation does not have such a strict and detailed regulation for the use of plastics in food, thus leaving producers free to use containers and materials that are not regulated but can be used for food.

\section{Regulation in other countries}

One of the most advanced countries in terms of packaging is Japan, which differs in the use of some materials authorized in the USA and Europe. Japan has the National Ministry of Health that tests and certifies food with its seal of safety and security, which gives assurance to consumers. In Japan, food contact materials are regulated by national legislation as well as voluntary industry standards.
The Food Sanitation Act enacted in 1947 regulates food, food additives, appliances and packaging/containers, and allows for further specifications. It is based on the food safety basic law. In addition, Notification No. 370 issued by the Ministry of Health and Welfare sets out the specifications and standards for food, food additives and other materials. In addition to the regulation of food contact materials, the Japanese regulation contains an article attributing liability to manufacturers for damages caused by their substances even when they comply with the legislation (Food Hygiene Law, Chapter 1, Art. 16). The legislation also sets out the rules under which migration tests are to be carried out, in order to ensure that an article will comply with the specifications (Japan Food Packaging Regulation, 2019). Thus, metal cans, glass/ceramic/enamel articles, and rubber and polymer articles have specific rules for each material and are supplemented by the specifications for 15 particular resins. In Mexico, legislation for packaging includes labelling, but in addition to regulation, a national label education campaign is required so that citizens first become interested in reviewing labels and knowing how to do so. Currently, many products are consumed in Mexico without any labels, and consumers are not concerned about the packaging of their food.

\section{Conclusions}

- There are few food-related standards compared to the food on the market.

- There are no standards by food groups, and they are not classified for easy access.

- Standards do not regulate the effect or impact of packaging components that may migrate into the food.

- There are not enough regulations to protect the consumer from the damage or effects of the packaging itself.

- Currently the labels do not mention that the packages may contain toxic substances.

- There is no culture of label reading. 


\section{References}

Contreras Jesús. (2002). Alimentación y Cultura. Necesidades, gustos y costumbres. Editorial Alfaomega. 1st Ed. Mexico. 9-23, 8588 p.p.

Careaga J. (1993). Manejo y reciclaje de los residuos de envases y embalajes. Ed. SEDESOL. Mexico DF. 55-70 pp.

Envapack, consultada en julio (2019). Available at: http:/www.envapack.com

Envasado y etiquetado. Consultado en julio de 2019 Available at: http://www.fao.org/3/y1453s0d.htm

Envases y normas - Santandertrade.com Recuperado en agosto de 2019. Available at: https://es.portal.santandertrade.com/gestionarembarques/mexico/envases-y-nomas

Forrest, Martin J. (2019). Recycling of Polyethylene Terephthalate. De Gruyter STEM, Kindle Edition.

Food and Agriculture Organizatation of the United Nations (FAO). (2009). Como alimentar al mundo en 2050. Recuperado en marzo 2019. Available at: http://www.fao.org/fileadmin/templates/wsfs/do cs/synthesis_papers/C\%C3\%B3mo_alimentar_ al_mundo_en_2050.pdf

Grisales M.; Giraldo M.; (2004). Envases biodegradables a partir de fibra de plátano para los productos agrícolas del departamento de Caldas. Bachelor Thesis. Universidad de Colombia. 4, 24 pp.

Lara E.; García E.; Regalado G.; 2005. Envases biodegradables comestibles con actividad antimicrobiana a base de proteína de suero. Universidad Autónoma de Querétaro. XI Congreso nacional de biotecnología y bioingeniería. Mérida Yucatán.

López A. 2008. Bioplásticos: efectos e impactos sobre la gestión de los envases. 9no congreso de nacional del medio ambiente. CONAMA. Madrid Spain.

Organización de las Naciones Unidas para la Agricultura y la Alimentación, (2010).
BISFENOL A (BPA) - Estado actual de los conocimientos y medidas futuras de la OMS y la FAO. Available at: https://www.who.int/foodsafety/fs_managemen t/No_05_Bisphenol_A_Nov09_sp.pdf

Pérez, C. (2012). Envases Y Embalajes. Red Tercer Milenio. Retrieved February 26, 2019, Available at: http://www.aliat.org.mx/BibliotecasDigitales/co municacion/Envases_y_embalajes.pdf

PET Resin Association . (2015). The Science Behind PET. Retrieved April 9, 2018. Available at:

http://www.petresin.org/science_behindpet.asp Food and Drug Association, FDA. (2018). Submissions on Post-Consumer Recycled (PCR) Plastics for Food-Contact Articles. Recuperado el 9 de abril del 2018. Available at: https://www.accessdata.fda.gov/scripts/fdcc/?se $\mathrm{t}=$ RecycledPlastics

Publicidad y nutrición. Consulted in July 2019 Available at: https://publicidadynutricion.wordpress.com/201 4/10/31/normatividad-y-legislacion-del-envaseenvase-y-embalaje/

Regulación sobre el envasado de alimentos en Japón

Food Packaging Forum

Recovered July 29, 2019. Available at: https://www.foodpackagingforum.org/es/envasa do-de-alimentos-y-salud/reglamentacion-sobreel-envasado-de-alimentos/food-packagingregulation-in-japan

Resumen de Salud Pública: Recovered Agust 2019. Available at: https://www.atsdr.cdc.gov/es/phs/es_phs20.htm 1

Secretaría de Economía, accessed July 2019. Available at: https://www.sinec.gob.mx/SINEC/Vista/Norma lizacion/BusquedaNormas.xhtml

Villada H.; Acosta H.; Velasco R.; (2007). Biopolímeros naturales usados en envases Biodegradables. Rev. Temas Agrarios Vol. 12:(2). 5-13 pp. 